\title{
インフォーマル市街地における開発形態の特質
}

ナイロビのインフォーマル市街地における空間マネジメントに関する研究 (1)

\section{DEVELOPMENT PATTERNS IN INFORMAL SETTLEMENTS}

Understanding the spatial formation and management of informal settlements in Nairobi (1)

\author{
小野＼cjkstart悠*, 城所哲夫** \\ Haruka ONO and Tetsuo KIDOKORO
}

\begin{abstract}
The purpose of this research was to empirically clarify the process of African urban development, with a focus on informal settlements, and to provide insights into the paradigms of urban planning in Africa. This paper explores development patterns of informal settlements using survey data from Nairobi, Kenya.
\end{abstract}

The results are as follows:

1. Spatial structure in informal settlements is not uniform.

2. Plot price is unaffordable for most residents, whereas room rent offers low-income residents a wide range of choices.

3. Informal settlements are not so much a place to live, but rather an attractive investment opportunity for structure owners.

\section{Keywords : Development pattern, Informal settlement, U rbanization, Nairobi, Africa 開発形態，インフォーマル市街地，都市化，ナイロビ，アフリカ}

\section{1.はじめに}

現在、アフリカは世界で最も急速に都市化が進行している地域で ある。都市に住む人口の割合は 1960 年にはわずか $15 \%$ あったが、 2010 年までに $40 \%$ に増加し、2050 年までには $60 \%$ になると予想さ れている ${ }^{1)}$ 。このような急激な都市化にもかかわらず、都市計画は 経済・行政の中心地区や富裕層が居住する住宅地区など都市の一部 で機能しているにすぎない。そのため、アフリカでは正規の土地所 有権がない、あるいは正規の開発許可手続きに則らずに開発された インフォーマル市街地に都市人口の $30 \sim 70 \%$ が居住している。 Berner $(2000)^{2)}$ によると新規に建設される住宅の $85 \%$ が無許可で あり、アフリカの市街化プロセスの大部分が都市計画の枠外で生じ ていると言える。また、一般的にスラムと呼ばれる貧困層が居住す る劣悪な環境の市街地だけでなく、中高所得層の住まいもまた都市 計画の枠外で形成されており 3)、アフリカにおけるインフォーマル な市街化は社会的・経済的階層を超えたプロセスである。

途上国都市におけるインフォーマル市街地の出現は、近代都市計 画の下でヨーロッパ的な空間と土着の空間という二重構造が生まれ た植民地時代に遡り ${ }^{4)}$ 、それは第二次世界大戦後の急激な都市化の 中で爆発的に拡大した。近代化・産業化・都市成長の原理に支えら れた 1960 年代までの都市政策理論においては、秩序ある近代都市
をつくる上での障害であり、撲滅すべき対象とみなされ、政府が資 本集約的な住宅供給を行うことでいずれはなくなるだろうと考えら れていた。これに対し、ラテンアメリカの研究を行っていた Turner は、インフォーマル市街地について「社会的に異常なものではなく、 類のない都市成長プロセスに対寸る自然な適応」と考え ${ }^{5)}$ 、政府に よる上下水道や道路への投資によって、インフォーマル市街地住民 は自ら住まいを改善することができるだろうという理論的戦略を主 張し、1970 年代以降の研究に大きな影響を与えた。

この Turner の主張に対して、土地権利のフォーマル化の重要性 を提唱したのが De Sotoである。De Soto は 2000 年に出版した「The Mystery of Capital」6)で、低・中所得国における貧困の原因は未発 達な土地所有制度にあると説明し、貧困層の土地権利をフォーマル 化することで市場へのアクセスを可能にし、住宅の改善やビジネス の開始を可能にすると論じた。2000 年以降は、世界の様々なフィー ルドでDe Sotoの主張についての検証が行われた。これらの研究を 広範にレビューした Durand-Lasserve \& Selod (2007) 7) と Payne et al.（2009）8は、インフォーマル市街地における土地登記あるい は土地権利証書の付与は概して大きな成果を出していないと結論づ けている注1)。また、土地権利のフォーマル化の負の側面 9)やフォー マル化の社会的・経済的難しさ10)11)についての指摘もなされるなど、 
De Soto が主張する土地権利のフォーマル化の効果は途上国都市の インフォーマル市街地では見いだせず、むしろインフォーマルな土 地権利もまた安全性を保証していることが明らかになった。

これまでのインフォーマル市街地に関する研究は、フォーマル・ インフォーマルという法に基づく二分法を前提として、いかにフォ ーマルな都市計画の枠組みにインフォーマルを組み込むかというこ とに問題関心を置いてきた。これに対して、このような二元的理解 から解放し、法の枠組みの中では見えなかった側面を明らかにする ことで、インフォーマル市街地の再概念化を試みる研究が見られる ようになっている。それはアフリカ都市を始めとする途上国都市に おける都市化現象をより本質的に理解しようとする試みであると言 える。Durand-Lasserve \& Selod（2007） 8)は、土地所有権は法の パラダイムの中で一元的に決まるのではなく、社会的関係性の中で 決まるため、インフォーマル市街地における土地権利は社会的関倸 性の中で理解しなければならないと論じている。また、Nkurunziza (2007） 12) はインフォーマル市街地で人々が宅地にアクセス寸るプ ロセスは無秩序・無規制ではなく、体系化され、社会的秩序によっ て規制され、その土地の文脈に応じた制度が発達していると論じて いる。さらに、その制度は法律や市場の規則、慣習など様々な規範 的秩序を利用しているとも論じている。インフォーマル市街地では 様々な規範的秩序を利用して地域に応じた制度を発達させていると いう捉え方は、インフォーマル市街地の実態を理解する上で新たな 視点をもたらすものであり注目に值する。

本研究は、アフリカ都市におけるインフォーマルな市街化プロセ スの実態を実証的に明らかにし、アフリカにおける都市計画のあり 方に資する知見を得ることを目的とする。急増する都市人口に対し て住宅供給が決定的に不足している途上国都市において、インフォ ーマル市街地は量的に住まいを供給しているという点において重要 であるとの認識は定着しつつある。しかし、インフォーマルな市街 化プロセスを法に基づく二元的理解ではなく、人々の関係性の中に その本質を見出そうとする研究は緒に就いたばかりである。本研究 は、インフォーマル市街地では様々な規範を参照した空間マネジメ ント（空間の形成・管理運営）が社会的関係性の中で発達し、その 空間マネジメントが開発形態に反映され、居住環境に影響を及ぼし ているとの仮説に基づく。本稿は、急激な都市化が進むケニア国ナ イロビを対象に、インフォーマル市街地における開発形態の特質の 把握を行うものである。

\section{2. ナイロビにおけるインフォーマル市街地の形成と市街化動向}

\section{1. インフォーマル市街地の形成と政策的対応}

1899 年にモンバサとビクトリア湖をつなぐウガンダ鉄道の中継 地点として設置されたナイロビはヨーロッパ人のための都市として 開発が始まった。植民地政府は黒人通行制限法を制定してアフリカ 人のナイロビへの移動を制限する一方、アフリカ人労働者を一定数 確保するために、居住地分離政策に基づいてアフリカ人労働者向け の公共賃貸住宅を供給した。しかし、移動制限にもかかわらず、多 くのアフリカ人がナイロビに流入し、住まいを確保するために掘建 小屋を建設した。ヨーロッパ人らはこれらインフォーマル市街地を 犯罪と病気の温床として恐れ、浮浪者取締法と公衆衛生法を根拠に 撤去を試みたが、結果的にインフォーマル市街地の再生産をもたら

\section{しただけであった。}

1963 年のケニア独立によって首都となったナイロビは、就業機会 を求めて農村からやって来る人々を大量に引きつけ、とりわけ、低 コスト住宅の需要が拡大した。新政府は公的資金を投入して住宅供 給を行ったものの、貧困層が入手可能な価格ではなかった。また、 民間セクターによって供給される住宅もまた先進国から移入した高 い水準を維持していたため、ナイロビの一般市民向けではなかった。 その結果、多くの人々が河川沿いや鉄道保留地など脆弱な土地に自 ら住まいを確保する他なかったため、インフォーマル市街地が急成 長した。

インフォーマル市街地に対しては、政府あるいは民間事業者・個 人による断続的な強制撤去、立ち退きが行われてきた。ナイロビで はインフォーマル市街地の法的位置付けがなく、包括的なスラム・ アップグレーディング政策の実施やフォーマル化の法的基盤整備が 行われないなど、政府がインフォーマル市街地の問題にほとんど対 処してこなかった。その要因には、(1)インフォーマル市街地の改善 政策はさらなるインフォーマル市街地の拡大をもたらすのではない かという不安からの政治的意思の欠如注 2)、(2)インフォーマル市街 地における政治的利害と民族集団間の対立の複雑化注 3 )、(3)ストラ クチャ・オーナーと借家人との利害関係の対立注 4 )、などがある。 そのため、インフォーマル市街地の環境改善を行っていくために新 たなアプローチが必要とされている。

\section{2. 市街化動向}

ナイロビは東アフリカにおける第 3 次産業の中心地として発展し てきた。1963 年の独立以来、人口増加率は年平均約 $5 \%$ を維持し、 現在、314万人 $\left(2009\right.$ 年) の人口を抱える中核的な大都市である ${ }^{16)}$ 。

Kajihara（2013）17)によると、同都市は、Fig.1 に示すように、中 高所得層の居住するフォーマル市街地が広がる西と、低所得者層の 居住するインフォーマル市街地が広がる東というように、所得水準 に基づいた空間的な分離が見られる。とくに住宅地のわずか $5.2 \%$ を占めるスラムには人口の 55 60\%以上が居住するなど、住宅需要 の重要な受け皿になっており、50,000 人/km²超す極めて高密度な 住環境を形成している。

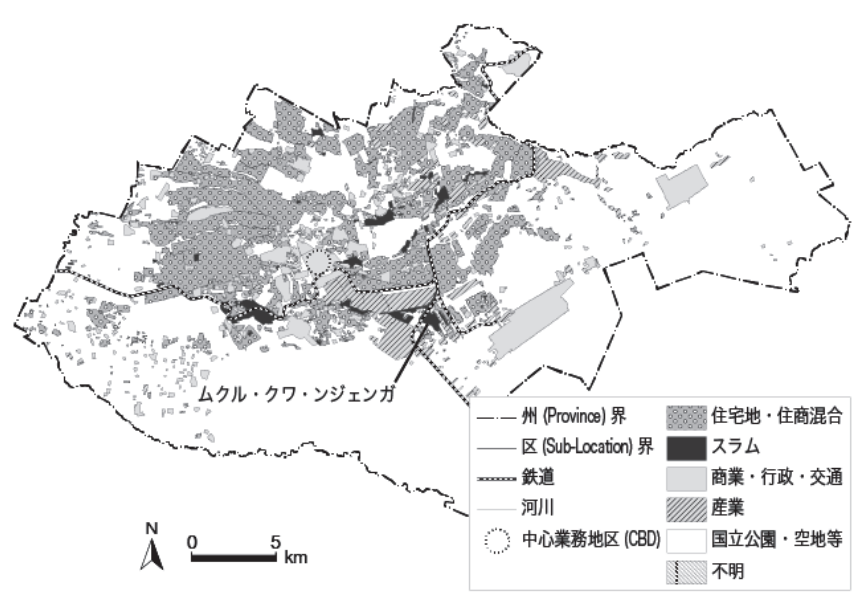

Fig.1 Nairobi Land Use

Source: Kajihara, 2013 


\section{3. 調査概要}

\section{1. ムクル・クワ・ンジェンガ地区の概況}

本研究では、ムクル・クワ・ンジェンガを調查対象として選定し た。ナイロビ中心部から約 $18 \mathrm{~km}$ に位置し、現在、面積 $1 \mathrm{~km} \mathrm{~m}^{2}$ に約 15 万人が居住している ${ }^{18)}$ 。植民地期は白人入植者が所有する大規模農 場であったが、後に政府が買収して産業地区となり、大部分の土地 が 1980 年代に民間個人に売却された。購入者の多くは投機目的で 土地を所有し、開発を行わずに放置していたため、就業機会や手頃 な住まいを求めて農村からやって来た人々が占有を始めた。

ムクル・クワ・ンジェンガは、Fig. 2 に示すように 8 ビレッジに 分かれる。もっとも早くに居住が始まったサイザルに続いて 1990 年代にはミリマニ、ベトナム、ゾーン 48（北部）が、1998〜2000 年にかけてジュアカリ (ベトナム内)、ゾーン 48 (南部)、リアラ、 ワペワペ、モトモト、MCC の開発が始まった。これらの中にはト タンでできた掘建小屋が雑然と立ち並ぶビレッジもあれば、コンク リート造高層集合住宅が整然と立ち並ぶビレッジもあり、異なる開 発形態が混在する。ナイロビでは一般的に土やトタンでできた仮設 の建物が立ち並ぶ市街地はスラムと呼称されるが、ムクル・クワ・ ンジェンガ内には一般的に呼ばれるところの“スラム”だけでなく、 コンクリート造の恒久的な建物が立ち並ぶ “都市的な”市街地も混 在している。本稿では、これらを正規の開発手続きを経ていないと いう点からまとめてインフォーマル市街地として研究対象とする。

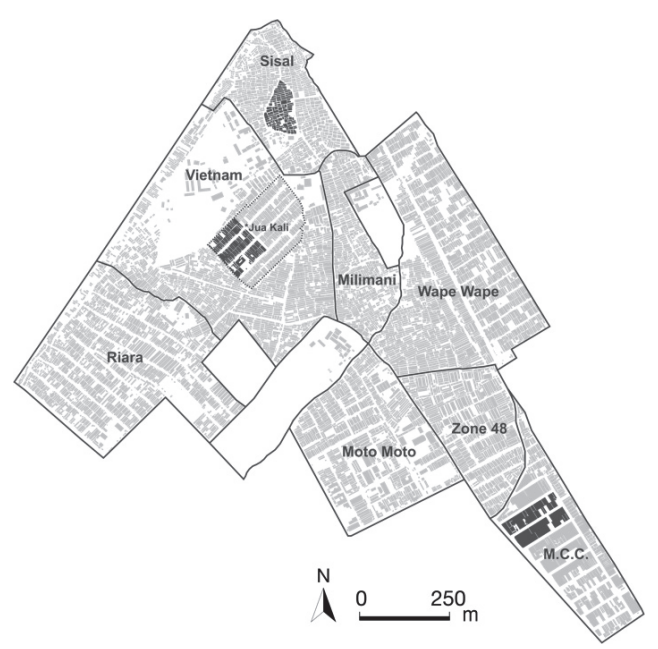

Fig.2 Map to show Mukuru Kwa Njenga

\section{2. 調查方法}

本調査では、インフォーマル市街地内の地区ごとの特性の共通点 と相違点を明らかにするため、ムクル・クワ・ンジェンガの 8 ビレ ッジのうち開発形態の特徴の異なるサイザル、ジュアカリ、MCC を調查対象地として選定した（Table1）。ジュアカリはベトナム・ ビレッジ内の一地区であるが、まとまった開発が行われ、周辺とは 異なる開発形態を有するため、地区の名前が付けられている。調査 は、2014 年 2〜 月の期間に、空間的特質、土地と借家のアフォー ダビリティ、開発主体の実態について実施した。空間的特質に関す る調査は、各地区の配置計画、建物プラン、建物の材料・高さ、建 造環境、建物用途に関寸る観察と実測調査を実施した。土地と借家 のアフォーダビリティと開発主体に関する調查は、当該建物の所有
者と住人へのインタビュー調査を実施した。

Table1 Basic information about the villages

\begin{tabular}{|l|c|c|c|}
\hline \multicolumn{1}{|c|}{ Village name } & Sisal & Jua Kali $^{\star}$ & MCC \\
\hline Area(km) & 0.092 & 0.0575 & 0.1013 \\
\hline Population & 11,427 & 6,999 & no data \\
\hline Year of the creation & 1985 & 2000 & 2000 \\
\hline
\end{tabular}

Notes $^{\star}$ : one area in Vietnam Village

Source: CURI, 2013

\section{4. 空間的特質}

本章では対象 3 地区の配置計画、建物プラン、建物の材料と高さ、 建造環境、建物用途に着目して、その空間的特質を明らかにする。

\section{1. 配置計画}

Fig.3 に敷地境界と建物配置を整理する。サイザルでは土地区画 のサイズや形状はまちまちであり、大小様々な形態の土地区画が杂隹 然と並んでいる。そのため、建物のサイズと形状もまた多様であり、 入り組んで立ち並び、細い街路が建物と建物の間を縫うように走っ ている (Fig.3 の photo)。一方、ジュアカリと MCC は約 $8 \mathrm{~m}$ の幅 員の比較的広い直線道路沿いに、一律 $33 \times 66$ フィート（約 $10 \times 20$ メートル）の短冊状に区画整理されていて、土地区画サイズと同程 度の建物が整然と立ち並んでいる（Fig.3の photo）。

\section{2. 建物プラン}

次に Fig. 3 に各地区の標準的な建物プランを整理する。4.1.で示 した通り、サイザルでは建物のサイズや形状が一様でないために建 物のプランも多様であるため、標準的な建物プランというものは存 在しない。しかし、基本的には長い棟に複数世帯が隣り合って居住 できるような長屋タイプの建物が多い。一方、ジュアカリと MCC では、土地区画サイズと形状が一律であるため、Fig. 3 に示す建物 プランが基本形となっている。ジュアカリの標準的なプランは回廊 を挟んでおよそ $10 \times 12$ フィート（約 $3.0 \times 3.7$ メートル）の部屋が 並び、共有のバスルームが設置されている。 MCC でも回廊を挟ん で部屋が並んでいるが、部屋はシングルルーム、ベッドシッター、 ワンベッドルームの 3 つの基本形がある。シングルルームはバスル 一ムとキッチンを共有するタイプの部屋、ベッドシッターはバスル 一ムとキッチンが付いた部屋（Fig.3）、ワンベッドルームはバスル ームとキッチン、リビング、一部屋の寝室のある部屋である。

\section{3. 建物の材料と高さ}

次に、建物に使われている材料を見ると（Fig.4）、サイザルとジ ユアカリではそれぞれ 92.3\%、92.5\%の建物でトタンが使用されて いるのに対し、MCC では $88.1 \%$ の建物でコンクリートが使用され ている。また、建物の高さについて見ると（Fig.5)、サイザルとジ ユアカリでは 1 階建ての建物がそれぞれ $80.0 \% 、 77.6 \%$ を占め、 2 階建てと 3 階建てがわずかに存在する。一方、MCC では 7 階建て まで存在し、低層（1２階建て）が $45.8 \%$ 、中層（ $3 \sim 5$ 階建て） が $27.2 \%$ 、高層（6〜 7 階建て）が $11.5 \%$ となっている。 MCC で は大部分の建物が建設途中であるため、将来的にはす心゙ての土地区 画に高層の建物が立ち並ぶものと考えられる。以上を整理すると、 サイザルとジュアカリでは $1 \sim 2$ 階建てのトタンの掘建小屋が大半 を占めるのに対し、MCC では最高 7 階建てのコンクリート造集合 住宅が主流となっていることが明らかになった。 


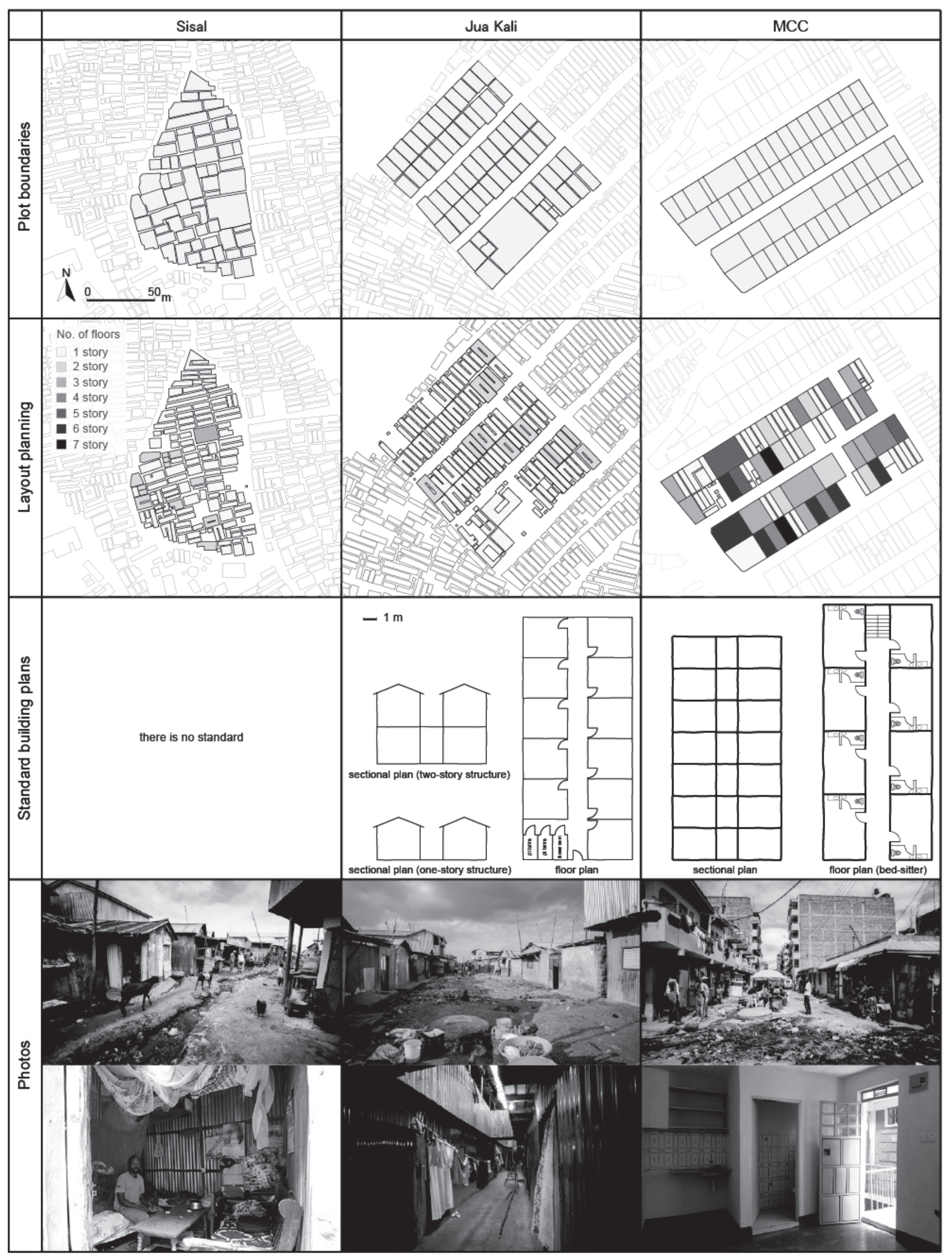

Fig.3 Housing layout

Source: Research findings. 


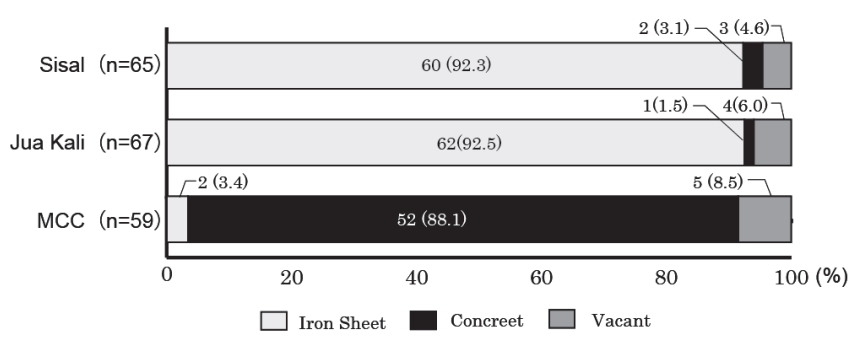

Fig.4 Construction material

Notes: number shown in parentheses is percent. Source: Research findings.

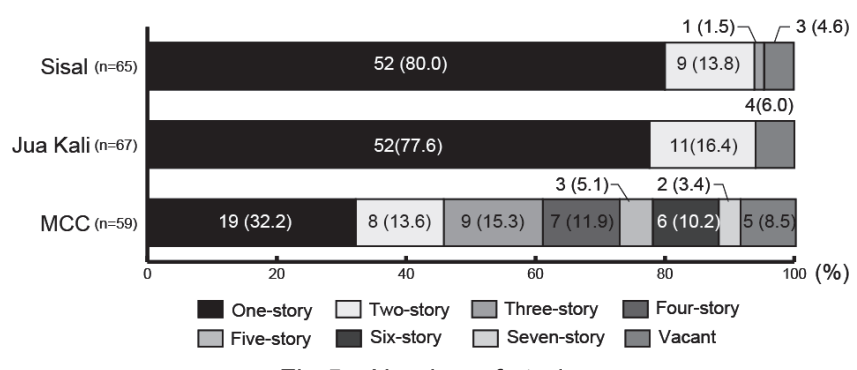

Fig.5 Number of stories

Notes: number shown in parentheses is percent. Source: Research findings.

\section{4. 建造環境}

以上から、3 地区の建ぺ率と容積率を計算した（Table2）。グ ロス建ぺい率は、サイザルが 56.8\%、ジュアカリが 59.4\%、MCC が $64.7 \%$ である。グロス容積率はサイザルが $66.8 \%$ 、ジュアカリが 71.1\%、MCC が 196.7\%となっている。3 地区で建ぺい率に大きな 違いが見られない一方で、容積率は MCC が他の 2 地区に比べて高 くなっている。先述の通り、MCC では多くの建物が建設途中であ り、また、建設の始まっていない空地も多数存在することから、現 段階では容積率が低く抑えられていると考えられる。しかし、いず れは寸べての土地区画で 7 階建て程度の建物が建つと予想され、そ の場合、容積率は 500\%を越える計算になる。

Table2 Built environment

\begin{tabular}{|l|r|r|r|}
\hline & \multicolumn{1}{|c|}{ Sisal } & \multicolumn{1}{c|}{ Jua Kali } & \multicolumn{1}{c|}{ MCC } \\
\hline Number of plots & 65 & 67 & 59 \\
\hline Gross building coverage ratio (\%) & 56.8 & 59.4 & 64.7 \\
\hline Gross floor area ratio (\%) & 66.8 & 71.1 & 196.7 \\
\hline
\end{tabular}

Notes $^{\star}$ : Calculated within the area surrounded by medial line of street surrounding the studied area

\section{5. 建物用途}

ムクル・クワ・ンジェンガ内には住宅だけでなく、人々の日常生 活に必要な物やサービスを提供する商店、飲食店、学校、クリニッ クなどが営まれている。業種としては、小売り、サービス、飲食、 娛楽、宿泊、製造、金融、医療、保育・学校教育、宗教など多様で ある。ここでは、建物の利用状況を「住宅専用」、「店舗その他の併 用住宅」、「店舗その他」に分類する。「店舗その他の併用住宅」は、 道路に面した部屋で商業・業務利用が行われ、奥の部屋に住人が居 住しているタイプの建物である（photo1）。建物 1 階の道路に面す る部屋は商業・業務利用しやすいように道路側に小空が取り付けて
あり、他の部屋に比べてやや高めの家賃設定になっている。また、 「店舗その他」は居住者のいない商業・業務専用の建物である。ム クル・クワ・ンジェンガでは、「店舗その他の併用住宅」と「店舗そ の他」が連続して並ぶことで商店街が形成され、住民の日常的な買 い物の場かつビジネスの場として賑わいを創出している。

Fig.6 に地区別の建物用途を示している。サイザルとジュアカリ では「住宅専用」が $70.8 \% 、 61.2 \%$ と大半を占め、また「店舗その 他の併用住宅」が $21.5 \%$ 、29.9\%を占めるなど、居住に特化した性 格の市街地であると言える。一方、MCC では、「住宅専用」が $25.4 \%$ と低く抑えられ、「店舗その他の併用住宅」が $55.9 \%$ 、「店舗その他」 が 8.5\%を占めており、商業・業務の利用が多いことが分かる。 MCC では高層集合住宅 1 階の道路に面した部屋が標準的に商業・業務利 用向けに作られているが、これは幹線道路に近いという立地的特性 から、ビジネスの場に適した環境にあるためと考えられる。

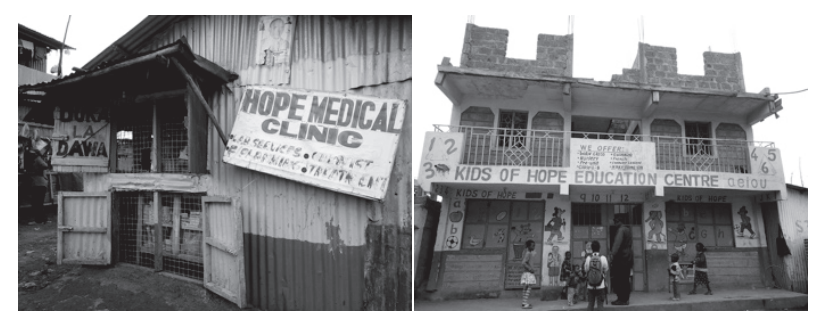

Photo1 Medical clinic (left) and nursery school (right) attached to dwelling

Source: Author

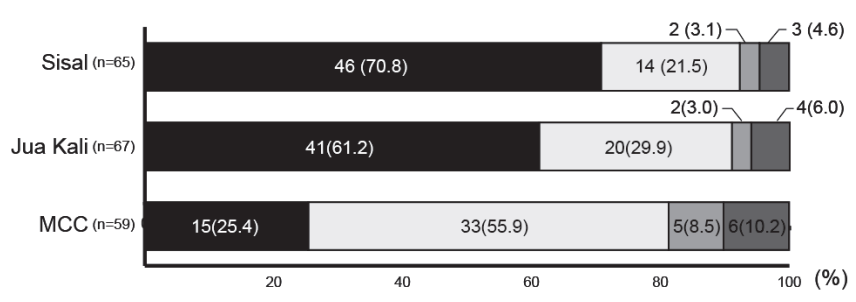

$\square$ Dwelling only $\square$ Dwelling with shop $\square$ Shop only $\square$ Vacant/Under construction

Fig.6 Structure use

Notes: number shown in parentheses is percent. Source: Research findings.

5. 土地と借家のアフォービリティ

ムクル・クワ・ンジェンガにおける土地や借家の価格はどのよう に設定されているのだろうか。一般に、インフォーマル市街地は正 規に住宅を購入したり、借りたりする費用を負担できない所得レ心゙ ルの低い人々が居住していると考えられているが、低所得者にとっ てアフォーダビリティは確保されているのだろうか。本章では、無 理のない負担で住宅に居住できることをアフォーダビリティと捉え、 ムクル・クワ・ンジェンガにおける土地と住宅のアフォーダビリテ イについて明らかにする。

\section{1. 土地のアフォーダビリティ}

ムクル・クワ・ンジェンガの土地を法的に所有しているのは、民 間の個人や企業である。しかし、同地域で建物を建設しているのは ストラクチャ・オーナーと呼ばれる土地所有者であり、彼らは法的 
な土地所有権を有さずに、建物を建設して部屋を貸貸している注5)。 一般的に土地の価格はストラクチャ・オーナーによって決められ る。ストラクチャ・オーナーへのインタビューからは、「土地価格は その土地に何部屋作れるかでおおよそ決まる」、「土地は年々高くな っている」といったように土地価格相場の形成が示唆される証言注 6) がある一方、「知り合いから相場よりも安く譲ってもらった」注7)、

「夫が亡くなり困笨していたため、ビレッジ・エルダー注8) から無 償でもらった」注9) といったような人と人との関係性の中で土地価 格が調整されていることを示寸証言も得られた。ストラクチャ・オ 一ナーが購入した土地の価格を、購入した時期と土地のサイズとの 関係性で示した Fig.7 からも、土地の価格設定がきわめて幅広いこ とが読み取れる。

2014 年現在、ムクル・クワ・ンジェンガで標準的なサイズ（約 $10 \times 20$ メートル）の土地を購入しようとすると、少なくとも 10 万 $\mathrm{ksh}$ 程度は寸る。CURI ${ }^{18)}$ によると、平均的な 1 日の稼ぎが $500 \mathrm{ksh}$ 以下であるムクル・クワ・ンジェンガの住民にとってはとても手の 届く価格ではない。逆に、土地を購入しているストラクチャ・オー ナーはかなり所得水準が高いと考えられる。一般にストラクチャ・ オーナーは定期的な家賃収入があり、違法とはいえ土地という資産 を有しているため、借家人に比べると生活の安定度は高く、ムクル・ クワ・ンジェンガの平均的な所得水準に比べてかなり高い水準であ ることが考えられる。

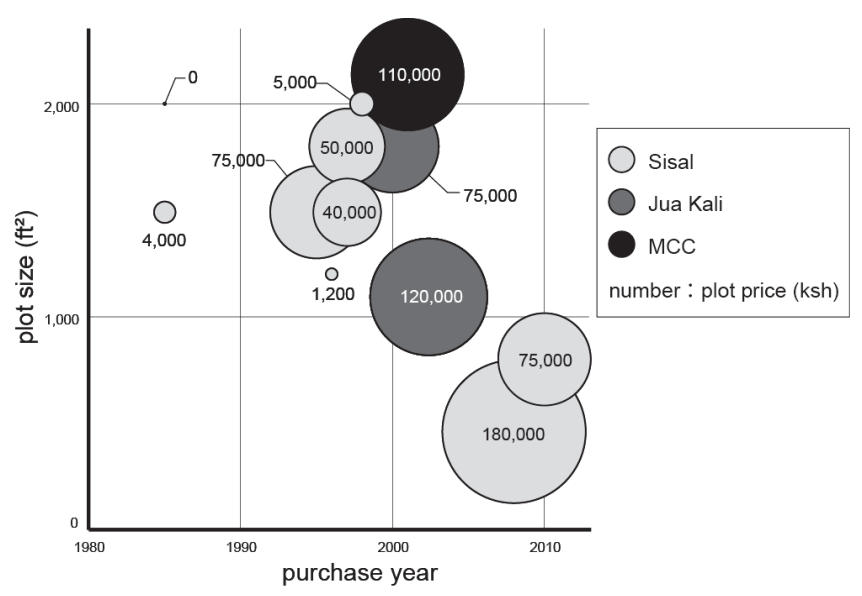

Fig.7 Plot price in relation to purchase year and plot size Notes: The number of samples: 9 plots in Sisal, 3 plots in Vietnam, 1 plot in $\mathrm{MCC}$

Source: Research findings.

\section{2. 借家のアフォーダビリティ}

借家の家賃もまたストラクチャ・オーナーによって決められてい る。Fig.8 に各地区で確認された家賃を示す。一般に家貨は、部屋 のサイズ、建物の構法・材料、部屋あるいは建物内における基本的 サービスの有無（水、トイレ、電気など）、立地（広幅員道路沿いか どうか、洪水地かどうかなど）、エリアの治安に影響されるが、地区 によっておおよその相場が確認できる。

サイザルは川沿いの低地に位置するため年間を通して地面がぬか るみ、治安が悪く、トタンの建物でトイレの設置もないところが多 いため、一部屋あたり $500 〜 1,500 \mathrm{ksh} /$ 月と、ムクル・クワ・ンジェ ンガでももっとも家賃が安いエリアである。また、ジュアカリはす
べての建物が広幅員道路に面し、トタンでできた建物内には共有卜 イレが設置されているため、一部屋あたり $1,500 \sim 2,000 \mathrm{ksh} /$ 月と、 サイザルに比べてやや高い家顀設定である。 MCC もすべての建物 が広幅員道路に面し、コンクリート造の建物にはトイレが設置され、 水や電気が供給されているため、ムクル・クワ・ンジェンガでは最 も家賃の高いエリアである。家賃は部屋のタイプによって異なり、 シングルルームで $3,500 \sim 5,000 \mathrm{ksh} /$ 月、ベッドシッターで 5,500 〜

$7,500 \mathrm{ksh} /$ 月、ワンベッドルームで $8,000 \sim 12,000 \mathrm{ksh} /$ 月である。

近隣のフォーマルな集合住宅の家賃は $50,000 \mathrm{ksh} /$ 月〜であるこ とを考えると、ムクル・クワ・ンジェンガではフォーマルな住宅市 場で供給されない家賃設定の低い住宅が供給されていると言えよう。 また、ムクル・クワ・ンジェンガには幅広い家賃帯があるため、収 入に合わせて住む場所を選ぶことが可能である。サイザルやジュア カリの住人がビジネスを成功させて収入が上がると MCC に引っ越 すなど、収入の増減に合わせた住み替えが行われている。

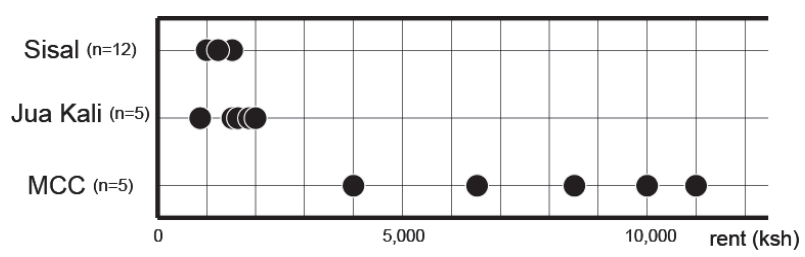

Fig.8 Room rent

Source: Research findings.

\section{6. 開発主体の特性}

先述の通り、ムクル・クワ・ンジェンガで建物を建設しているの は、法的な土地所有権を有していないストラクチャ・オーナーと呼 ばれる土地所有者である。Fig.9 は各土地区画内の居住者属性を示 している。いずれの地区でもストラクチャ・オーナーのみが居住す る土地区画は存在せず、ストラクチャ・オーナーと借家人、あるい は借家人のみが居住している。ストラクチャ・オーナーの当該土地 区画での在住率は、サイザルで $26.2 \%$ 、ジュアカリで $13.4 \%$ 、MCC で $6.8 \%$ といずれも低いことから、ストラクチャ・オーナーは不在地 主化して利益追求的に建物の建設と部屋の賃貸を行っているものと 考えられる。ストラクチャ・オーナーにとって、インフォーマル市 街地は居住の場所というより、投資先として魅力的であると言えよ う。そしてその傾向はサイザルよりも MCC において強いと考えら れる。

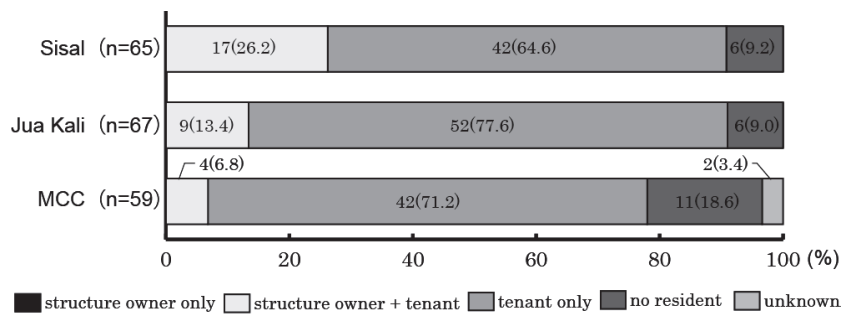

Fig.9 Residents living in the plots

Notes: number shown in parentheses is percent. Source: Research findings.

またストラクチャ・オーナーの中には複数の土地区画を所有して 
いる者も多数存在する。例えば、サイザルのストラクチャ・オーナ 一の中にはサイザルに 2 区画、ベトナムに 1 区画、ミリマニに 1 区 画の土地を注１0)、ジュアカリのストラクチャ・オーナーの中にはジ ユアカリに 3 区画の土地を注 11 1)、MCC のストラクチャ・オーナー の中には MCC で 1 区画、ナイロビ中心部のフォーマル市街地で 1 区画の土地を所有して賃貸経営している者注 12$)$ が確認できた。ス トラクチャ・オーナーの中には自らはフォーマル市街地に居住して、 ビジネスとしてムクル・クワ・ンジェンガで土地を購入し、建物を 建設して賃貸経営を行うデベロッパー的性格の強い者も多数存在す ることが明らかになった。自分は低コストの住宅供給を行ってわず かばかりの利益をあげながら、人々の住まいに対するニーズに応え ている」と証言するストラクチャ・オーナーもいた注11)。

\section{7. 結論}

最後に、インフォーマル市街地の開発形態について、本研究で得 られた知見をまとめる。

（1）インフォーマル市街地における空間的構造は均一でなく、多 様であることが明らかになった。すなわち、トタンで作られた掘立 長屋住宅が雑然と立ち並ぶいわゆる“スラム”、コンクリート造の高 層集合住宅が整然と立ち並ぶ“都市的な”市街地、そしてその中間 的な空間的特徵を有する市街地が確認された。

（2）インフォーマル市街地における土地には幅広い価格設定が見 られるが、“スラム”であれ、“都市的な”市街地であれ、概して貧 困層が大部分を占める住人には手が届かない。一方、部屋の家賃は、 部屋のサイズ、建物の構法・材料、部屋あるいは建物内における基 本的サービスの有無（水、トイレ、電気など）、立地（広幅員道路沿 いかどうか、洪水地かどうかなど）、エリアの治安に影響される。“ス ラム”に比べて、“都市的な”市街地における方が家顀の設定は高い 傾向にある。居住環境の違いによって幅広い家賃設定が行われ、低 所得者向けに多くの選択肢が用意されていると言える。

（3）ストラクチャ・オーナーの多くが不在地主化して、利益追求 的に建物を管理運営している。複数の建物を所有する者もおり、ス トラクチャ・オーナーにとってインフォーマル市街地は居住の場所 というより、投資先として魅力的であると言えよう。また、このよ うな傾向は“スラム”よりも“都市的な”市街地で顕著である。

本研究では急激な都市化が進むナイロビのインフォーマル市街地 を対象に、開発形態の多様性を実証的に明らかにした。今後、異な る開発形態を有する市街地がどのように形成・管理運営されている のか、空間マネジメントの実態を明らかにしていく必要がある。

\section{謝辞}

本研究は JSPS 科研費（特別研究員奨励費 249053）を受けて実 施した。現地調査では Peter Ngau 氏（University of Nairobi）、 Joseph Mwendo 氏（Muungano Wa Wanavijiji）、ムクル・クワ・ ンジェンガの住民など、多くの方のご協力をいただいた。末筆なが ら、ここに記して感謝いたします。

\section{参考文献}

1) UN-HABITAT: The State of African Cities 2010: Governance, Inequality and Urban Land Markets, 2010

2) Berner, E.: Learning From Informal Markets: Innovative Approaches to
Land and Housing Provision, 2000

3) Anyamba, T.J.C.: Diverse Informalities" Spatial Transformations in Nairobi, VDM Verlag, 2008

4) Myers, G.: Defining Power: Forms and Purposes of Colonial Model Neighbourhoods in British Africa, Habitat International, 27, pp.193-204, 2003

5) Turner, J. F. C. and Fichter, R. eds.: Freedom to Build: Dweller Control of the Housing Process, Macmillan: New York, 1972 $<\mathrm{http}: / /$ www.communityplanning.net> (accessed 2017.2.5)

6) De Soto, H.: The Mystery of Capital: Why Capitalism Triumphs in the West and Fails Everywhere Else, Basic Books, 2000

7) Payne, G., Durand-Lasserve, A. \& Rakodi, C.: The Limits of Land Titling and Home Ownership, Environment and Urbanization, Vol 21(2), pp.443-462, 2009

8) Durand-Lasserve, A. and Selod, H.: The Formalisation of Urban Land Tenure in Developing Countries, 2007

9) Benjaminsin, T.A., Holden, S., Lund, C.and Sjaastad, E.: Formalization of Land Rights: Some Empirical Evidence from Mali, Niger and South Africa, Land Use Policy, 26, pp. 28-35, 2008

10) Magigi, W. and Majani, B.B.K.: Community Involvement in Land Regularization for Informal Settlements in Tanzania: A strategy for Enhancing Security of Tenure in Residential Neighborhoods, Habitat International, 30, pp. 1066-1081, 2006

11) Ono, H., Maeshima, A., Kidokoro, T. and Shima, N.: Land Issues in Residential Area in Lusaka, Zambia, Journal of Architecture and Planning (Transactions of AIJ), Vol.77, No.675, pp.1139-1144, 2012. 5(in Japanese)

小野悠，前島彩子，城所哲夫，志摩憲寿：ザンビア・ルサカの住宅地におけ る土地問題に関する一考察，日本建築学会計画系論文集，第 77 巻第 675 号， pp.1139-1144, 2012.5

12) Nkurunziza, E.: Informal Mechanisms for Accessing and Securing Urban Land Rights: The Case of Kampala, Uganda. Environment and Urbanization, 19(2), pp.509-526, 2007

13) Fernandes, E., and Varley, A.: Law, the city and citizenship in developing countries: An introduction. In Fernandes, E. \& Varley, A. (Eds.), Illegal cities: Law and urban change in developing countries. London: Zed., 1998

14) Weru, J.: Community Federations and City Upgrading: The Work of Pamoja Trust and Muungano in Kenya, Environment\&Urbanization, Vol.16, No.1, pp.47-62, 2004

15) Housing Research and Development Unit University of Nairobi: Mathare Valley: A Case-Study of Uncontrolled Settlement in Nairobi, 1971

16) Kenya National Bureau Statistics: 2009 Kenya Population and Housing Census, 2010

17) Kajihara, H.and Kidokoro, T.: The Impact of Land Tenure System on Informal Urban Development in African Cities: A Case Study of Nairobi, Lusaka and Dakar, Journal of the City Planning Institute of Japan, Vol.48, No.3, pp.225-230, 2013.10 (in Japanese)

梶原悠, 城所哲夫：アフリカ都市におけるインフォーマル市街地の形成と 土地制度の特質に関する研究 -ナイロビ、ルサカ、ダカールを事例に-, 日 本都市計画学会学術研究論文集 48-3, pp.225-230, 2013.10

18) Centre for Urban Research and Innovations (CURI) and University of Nairobi: Mukuru Kwa Njenga Slum Upgrading Project, 2012

注

注 1) Durand-Lasserve \& Selod（2007）と Payne et al.（2009）は広範な研 究レビューにより、以下の点を明らかにした。土地登記による土地と住宅 への投資、フォーマルな融資へのアクセス、自治体の歳入の増加は、イン フォーマルな土地権利の下にある場合に比べて顕著ではない。土地権利証 書の付与によって貧困レベルが優位に減少しているという証拠はない。土 地登記は土地権利の安全性を高めるが、インフォーマルな土地権利もまた 高いレベルの安全性を保障している。多くの国では土地登記は必ずしも立 ち退きや土地収用から人々を保護するわけではない。土地登記を行っても 銀行は低所得世帯に融資しないが、低所得世帯もまた銀行から借金をしよ うとは思わない。土地登記は必ずしもインフラやサービス供給を改善しな 
いが、一方で多くのインフォーマル市街地では土地登記が行われることな くインフラやサービス供給が改善されている。

注 2) Fernandes \& Varley（1998）（文献 13）は、政府がインフォーマル市 街地の問題にほとんど対処してこなかった理由の一つとして、「スラムの 環境改善を促進するいかなる政策もさらなる違法性の“門戸を開く”のて はないかという不安があった」ことをひとつの要因として指摘している。 インフォーマル市街地の劣悪な環境を放置することは政府への批判をもた らす危険性があるが、政府は選挙期間中などにインフォーマル市街地の有 力者に現金をばらまくことで不満を抑えてきた。

注 3）インフォーマル市街地における住民の民族構成は極めて多様であるが、 異なる民族出身者が大統領候補となったことで引き起こされた 2007 年の 選挙後暴動に見られるように、政治的な利害対立が民族集団間の関係性を 複雑化し、環境改善に向けた合意形成を困難にしている（文献 14）。

注 4) アップグレーディングプログラムにおいて、ストラクチャ・オーナーは 自らの建物が占有する土地の法的な所有権を承認してもらいたい一方、借 家人は現居住場所の占有権だけでなく、その建物と土地の所有権も認めて もらいたいと考えている（文献 15）。このような優先事項の違いによる対 立関係がプログラムの遂行を困難にする一方、アップグレーディングにお ける土地所有の正規化に対しては両者とも懸念を抱いている。なぜなら、 土地所有の正規化が決定すると、土地の值上がりを見越した富裕層や政治 的コネクションを持つ者らによる土地の買い占めや強奪が生じて、ストラ クチャ・オーナーは建物を失い、借家人は家貨の高騰により住み続けるこ とが困難になるからである。

注 5）ムクル・クワ・ンジェンガの土地は、植民地期には白人入植者が所有す る大規模農場であったが、独立後、政府が買収して産業地区になった。1980 年代、政府はこの土地の大部分を政府支援者など民間個人に売却した。こ うして法的な土地所有者となった者の多くは開発を行わずに投機目的で土 地を所有していたため、政府や民間セクターが供給する住宅にアクセスで きない人々が法的な土地所有者に無断で土地を占拠して住まいを構えるよ うになった。

注 6) サイザルのビレッジ・エルダーへのインタビューによる (2014.5.14)

注 7）サイザルのストラクチャ・オーナーへのインタビューによる (2014.3.25)

注 8）ビレッジ・エルダーはビレッジの土地や住民を管理するビレッジ・コミ ティの長である。

注 9）サイザルのストラクチャ・オーナーへのインタビューによる (2014.6.10)

注 10）サイザルのストラクチャ・オーナーへのインタビューによる (2014.6.10)

注 11） ジュアカリのストラクチャ・オーナーへのインタビューによる (2014.7.5)

注 12）MCC のストラクチャ・オーナーへのインタビューによる（2014.7.3） 


\section{DEVELOPMENT PATTERNS IN INFORMAL SETTLEMENTS}

Understanding the spatial formation and management of informal settlements in Nairobi (1)

\section{Haruka ONO* and Tetsuo KIDOKORO**}

* Assist. Prof., Toyohashi University of Technology, Dr.Eng.

** Assoc. Prof., Dept. of Urban Engineering, University of Tokyo, Dr.Eng

Cities in Africa are growing rapidly, but urban planning is lacking. Urban populations have few options and end up finding housing in informal settlements, which are developed without government-controlled urban planning resources. Informal settlements have become a major dynamic in African urbanization.

The purpose of this research was to empirically clarify the process of African urban development, with a focus on informal settlements, and to provide insights into the paradigms of urban planning in Africa. At the first onset, this paper explores development patterns of informal settlements using survey data from Nairobi, Kenya.

This area of focus is the Mukuru Kwa Njenga settlement, which was illegally formed in an industrial area and houses approximately 150,000 people in a one square kilometer area. This case study was conducted onsite via field surveys using observation, measurements, and interviews by specifically examining layout planning, material, building plan and use, building coverage ratios, plot ratios, housing and land affordability, and characteristics of developers.

The results are as follows:

(1) Spatial structure in informal settlements is not uniform. For example, we identified squatter areas with iron sheet houses and narrow streets, planned areas with high-rise buildings made of concrete blocks arranged in a perfect array, and intermediate conditions.

(2) In informal settlements, structures are built and rented to tenants by plot owners who are referred to as structure owners. As a general rule, plot price and room rent are set by structure owners. Plot price, which is related to plot size and the presence or absence of access roads, is unaffordable for most residents. In contrast, room rent, which is related to the size and type of room, the presence or absence of basic services in the room or plot (such as water, sanitation, and electricity), land conditions (such as roadside, low-lying, and flooded areas), and security, is generally fixed in accordance with the area and offers low-income residents a wide range of choices.

(3) Few structure owners reside in their own structure, and others are non-residents who build and rent structures for profit. Some own and manage more than one structure. Therefore, informal settlements are not so much a place to live, but rather an attractive investment opportunity for structure owners or developers. This tendency is more applicable in planned areas than in squatter areas in informal settlements. 